\title{
$\widehat{A}$ Madridge \\ madridge Journal of Vaccines \\ Interconnecting Scientific World
}

Research Article

Open Access

\section{Rabies vaccine purification using HPLC, Estimation of residual vero cellular DNA by RT-PCR and potency analysis}

Thangaraj Sekar ${ }^{\star}$, Ananda Arone Premkumar, Ganesan Chandra Mohan, Balaraman Sekar, Bheeman Sundaran and Sakthivel Sivakumar

Pasteur Institute of India, Coonoor, The Nilgiris, Tamilnadu, India

Article Info
*Corresponding author:
Thangaraj Sekar
Assistant Research Officer
Research and Development Laboratory
Pasteur Institute of India Coonoor
The Nilgiris Tamilnadu, India
Tel: +919487365795
E-mail: sekar_102000@yahoo.com

Received: December 12, 2018

Accepted: February 11, 2019

Published: February 18, 2019

Citation: Sekar T, Premkumar AA, Mohan GC, Sekar B. Rabies vaccine purification using HPLC, Estimation of residual vero cellular DNA by RT-PCR and potency analysis. Madridge J Vaccines. 2019; 3(1): 66-70.

doi: 10.18689/mjv-1000115

Copyright: @ 2019 The Author(s). This work is licensed under a Creative Commons Attribution 4.0 International License, which permits unrestricted use, distribution, and reproduction in any medium, provided the original work is properly cited.

Published by Madridge Publishers

\begin{abstract}
The rabies is a highly fatal, viral zoonotic disease can be preventable by effective vaccination. The anti-rabies vaccine prepared by cell culture technology are safer than the nerves tissue vaccine. The PV-11 strain of rabies virus was propagated in vero cells and subjected for purification using HPLC and potency analysis in this study. The viral harvest were concentrated up to $10 \mathrm{X}$ by tangential flow ultra-filtration with $100 \mathrm{kDa}$ MWCO cassettes. The vero cell DNA in the concentrated material were removed by protamine sulfate precipitation and the virus inactivated by $\beta$ propiolactone. The inactivation of virus was assured through Avirulece test, virus amplification test and PCR. The vero cell DNA in different stages of vaccine preparation were quantified by real time - PCR. It was estimated that maximum of $94.85 \mathrm{pg}$ in viral harvest, $119.4 \mathrm{pg}$ in concentrated material and $23.6 \mathrm{pg}$ in final purified vaccine. The rabies viral protein was detected through HPLC analytical column in comparison with the international standard reference vaccine and purified by preparative column. Further dot blot hybridization assay was performed to quantify the rabies viral protein. The purified preparation was sterile filtrated through $0.22 \mu$ filtration, formulated with two different preservative and stabilizers. The final vaccine was lyophilized in vials under aseptic condition, subjected for NIH Potency analysis in mice model to estimate the potency unit of our vaccine preparation and the potency units were calculated using the probit analysis software in comparison with international standard reference vaccine. The potency unit of 4 different samples from two different formulations were measured. The potency unit of batch 1 formulations were 5.72 and $6.34 \mathrm{IU} /$ single dose and batch 2 formulations were 2.80 and $2.89 \mathrm{lU} /$ single dose. Both the vaccines passes the minimum requirement of $2.5 \mathrm{IU} / \mathrm{single}$ dose.
\end{abstract}

Keywords: Rabies vaccine; Purification; HPLC analysis; Vero DNA; RT-PCR; NIH potency.

\section{Introduction}

Rabies is a ancient viral zoonotic disease that is invariably fatal in humans and mammals [1]. Rabies virus causes an acute encephalitis in all warm-blooded hosts including humans. 50 - 55 thousand people dying from rabies worldwide each year and over 3 billion people continuing to be at risk of rabies virus infection in over 100 countries [2]. India is reported to have the highest incidence of rabies globally [3]. The non-segmented negative-stranded RNA genome of rabies virus codes five structural proteins namely $\mathrm{N}$ (nucleo protein), G (glycol protein), M1 (phosphor protein), M2 (matrix protein), and L (polymerase) [4]. Effective vaccination is one of the most important element in the control of human rabies. The vaccines produced in mammalian neural tissues have been in use for more than 100 years [5]. 
Rabies vaccines produced in mammalian neural tissues have the disadvantages of causing severe adverse reaction [6-7], at a rate estimated as 0.3 to 0.8 per thousand treated patients. World Health Organization (WHO) has recommended since the 90's that they have to be replaced by vaccines produced in substrates free from animal nervous tissues, as the later are more immunogenic, safe and potent vaccines produced by cell culture techniques are available and used for pre and post exposure prophylaxis [8-9].

The use of cell culture derived vaccines should meet the quality requirements of world health organization guidelines and necessary steps to be followed during purification of the vaccine to reduce the contaminants like residual cellular DNA, test for pyrogenic substances and other cellular proteins [5].

\section{Material and Methods}

\section{Animal model}

The Swiss albino mice bred in Pasteur Institute of India, Coonoor which is registered under CPCSEA (Committee for the purpose of control and supervision of experiments on animals), maintained according to the guidelines and use of these animals has the approval of Institutional Animal Ethics Committee (IAEC) of Pasteur Institute of India, Coonoor.

\section{Vero cell and rabies virus propagation}

Cryo preserved vero cells in the passage 140 was revived, sub cultured and used as host system for rabies virus. PV 11 strain of rabies virus was propagated by roller bottle and bioreactor culturing methods, four viral harvest were collected from each culturing methods and subjected for downstream processing and analytical procedures.

\section{Concentration of viral harvests}

The viral harvest were centrifuged at $2,500 \mathrm{~g}$ for 10 minutes under the refrigerated $\left(4^{\circ} \mathrm{C}\right)$ condition to pelletize the cellular debris and clarified with $0.45 \mu$ filtration. The supernatant was aseptically collected in a sterile container. The four viral harvests were pooled and subjected for $10 \mathrm{X}$ concentration with 100 kDa MWCO (molecular weight cutoff) cassette (100 K B100-A 0.1 SQ.M) in a tangential flow ultra-filtration unit (Millipore). During the concentration process the feed pump was fixed at $500 \mathrm{rpm}$ to maintain the pressure around 2.7 bar and the temperature between $12^{\circ} \mathrm{C}$ - $18^{\circ} \mathrm{C}$. Ten litres of sterile cold PBS ( $\mathrm{pH} 7.4$ ) was used in recirculation mode at the end of the concentration process and collected the virus concentrates aseptically.

\section{Removal of vero cellular DNA}

The vero cellular DNA in the in-process material was treated with protamine sulfate (sigma) at the final concentration of $2 \mathrm{mg} / \mathrm{ml}$ and incubated for 2 hours at $4{ }^{\circ} \mathrm{C}$ (wet ice) [10] with mild shaking. The Vero cell DNA in the inprocess material were precipitated and removed by centrifugation at $25,000 \mathrm{~g}$ for 10 minutes at $4^{\circ} \mathrm{C}$. The supernatant containing the rabies virus were collected and subjected for virus inactivation.

\section{Virus inactivation}

The concentrated virus material was clarified by $0.45 \mu \mathrm{m}$ filtration. The $\beta$ propiolactone (BPL) was used as inactivating agent in the concentration of $1: 4000(\mathrm{v} / \mathrm{v})$ at $4^{\circ} \mathrm{C}$ for seven days with shaking of $60 \mathrm{rpm}$. $[6,9,11]$.

\section{Test for virus inactivation}

\section{Avirulece test to ensure the inactivation in mice model}

10 number of mice per sample in the weight ranging from 12 to 15 grams were taken and $0.03 \mathrm{ml}$ of the inactivated sample per mouse inoculated intracerebrally. The mice were observed for 14 days for typical symptoms of rabies and death.

\section{Virus amplification test on Vero cells followed by inoculation in mice}

Corresponding volume of 25 dose of concentrated, inactivated in-process biological material was seeded in 70 to $80 \%$ monolayer of vero cells and kept at $37^{\circ} \mathrm{C}$ for one and half hours for adsorption [12]. Two sterile PBS washes were given to remove the inactivated materials from cell line other than the adsorbed virus. The fresh maintenance media was replenished and continued the incubation at $37^{\circ} \mathrm{C}$ for 14 days During the incubation period, fluid change (maintenance media) were done on $7^{\text {th }}$ and $12^{\text {th }}$ day of incubation. The fluid was collected on $14^{\text {th }}$ day and replenished with fresh maintenance media and continued the incubation for another seven days. Finally the fluid was collected on $21^{\text {st }}$ day of incubation. The $14^{\text {th }}$ and $21^{\text {st }}$ day harvested fluid were inoculated into mice model as described in Avirulece test mentioned above.

\section{Inactivation of virus ensured by multiplex PCR (Polymerase Chain Reaction)}

The $14^{\text {th }}$ and $21^{\text {st }}$ day harvested fluid from the virus amplification test (as described above) were subjected for mRNA isolation using Macherey-Nagel Nucleo Spin viral RNA isolation kit and cDNA conversion through iScript cDNA conversion kit (bio-rad) as per the manufacturer instruction. The samples were analyzed for the presence / absence of rabies virus specific genome amplification with the multiplex PCR. 40 $\mathrm{\mu l}$ master mix per reaction was prepared with two pairs of primers (NP \& MP gene specific primer) and amplified in eppendrof thermal cycler (nexus GSX1) with the following amplification cycle; initial denaturation at $94^{\circ} \mathrm{C}$ for $5 \mathrm{~min}$ followed by $94^{\circ} \mathrm{C}$ for $30 \mathrm{~s}, 59^{\circ} \mathrm{C}$ for $45 \mathrm{~s}, 72^{\circ} \mathrm{C}$ for $45 \mathrm{~s}$ for 35 cycles with final extension at $72^{\circ} \mathrm{C}$ for $7 \mathrm{~min}$ [13].

\begin{tabular}{|c|c|c|c|c|}
\hline Gene & Primer Pairs & Location & $\begin{array}{c}\text { Annealing } \\
\text { temperature }\end{array}$ & $\begin{array}{c}\text { Product } \\
\text { size }\end{array}$ \\
\hline \multirow{2}{*}{ NP } & $\begin{array}{l}\text { For: 5'-CGCCAAACTTGATCCTGACG-3' } \\
\text { Rev: 5'-AGTGACAACTGTGCCCACTC-3' }\end{array}$ & $\begin{array}{l}256-275 \\
763-744\end{array}$ & $59^{\circ} \mathrm{C}$ & $508 \mathrm{bp}$ \\
\hline \multirow{2}{*}{ MP } & $\begin{array}{l}\text { For: 5'-GATCCTGCGGCACATTCTGA-3' } \\
\text { Rev: 5'-TTCTGCCCCGGATATGACAC-3' }\end{array}$ & $\begin{array}{l}2705-2724 \\
2997-2978\end{array}$ & $59{ }^{\circ} \mathrm{C}$ & $293 \mathrm{bp}$ \\
\hline
\end{tabular}

Detection and purification of rabies viral protein by HPLC (high-performance liquid chromatography)

The inactivated in-process material was subjected for HPLC analysis using the analytical column (Luna $5 \mu \mathrm{c} 18(2)$ 100A \& Bio Sep 5um SEC-s2000 145A - Phenomenex). 70 \% 
Acetonitrile (Fisher scientific, HPLC grade) was used as mobile phase in the flow rate of $1.5 \mathrm{ml}$ per minute. $20 \mu \mathrm{l}$ of sample was injected and the peak of the rabies virus protein was identified using the international standard reference vaccine using PDA detector at the wavelength of $280 \mathrm{~nm}$.

The HPLC method was developed for the purification of rabies virus protein from the inactivated in-process material by using preparative column (Luna $15 \mu$ c18(2) 100A) in which the sterile filtered PBS ( $\mathrm{pH}$ 7.4) used as mobile phase at the flow-rate of $75 \mathrm{ml}$ per minute. Two $\mathrm{ml}$ of the sample was injected and the viral protein peak was collected separately in comparison with the reference vaccine peak retention time and used for the formulation of vaccine.

\section{Dot blot hybridization}

The dot blot hybridization was performed to detect and quantify the rabies viral protein in the purified preparation by in-house standardized method [14].

\section{Formulation of rabies vaccine}

Two different vaccine formulations ( $1 \mathrm{ml} /$ dose) were made with HPLC purified rabies antigen. The Batch 1 formulation consist of $1 \%$ human albumin, $5 \%$ maltose, and $0.015 \%$ of thiomersal and the Batch 2 formulation consist of $1 \%$ human albumin, $0.5 \%$ glycine, $1.0 \%$ sorbitol and $0.015 \%$ thiomersal [15]. The vials were lyophilized and stored at $+4^{\circ} \mathrm{C}$ until the potency analysis.

\section{Vero cellular DNA estimation by real-time PCR}

The quantity of residual vero cell DNA in the different viral harvests, concentrated and purified materials were monitored using real time based quantification technique. The DNA in the samples were isolated by Proteinase $\mathrm{K}$ lysis, phenol: chloroform: isoamyl alcohol (50:48:2) extraction followed by ethanol precipitation. The isolated DNA was subjected for real-time PCR analysis for the quantitative measurement using resDNA SEQ Quantitative Vero DNA kit (Roche light cycler 96) along with the standards provided with the kit. The following conditions were applied for the amplification and detection; pre-incubation (initial denaturation) at $95^{\circ} \mathrm{C}$ for 10 minutes followed 40 cycles of amplification $95^{\circ} \mathrm{C}$ for $15 \mathrm{sec}$ (denaturation), $60^{\circ} \mathrm{C}$ for $60 \mathrm{sec}$ (annealing $\&$ extension) as per the manufacturer instruction.

\section{NIH potency testing of rabies vaccine}

The rabies vaccine vial diluted to $1: 25,1: 125$ and 1:625 with PBS. 16 mice (12-15gram) per dilution were placed and injected $0.5 \mathrm{ml}$ of diluted vaccine to the respective group through intra-peritoneal route of immunization. On the 7th day booster immunization given with the same dilution of vaccine to the respective group of mice. After 7 days of booster, $0.03 \mathrm{ml}$ of challenge virus dose (CVS : 5 to $50 \mathrm{LD}_{50}$ virus) per mouse was inoculated intra- cerebrally to each set of immunized mice [18]. 40 Nos of unimmunized mice kept as control while setting up of the assay. During the challenge 10 control mice were inoculated with challenge dose as like immunized mice. Three times tenfold dilution of challenge dose were made and inoculated each dilution with 10 mice. Rabies specific symptoms and death were observed on the challenged mice for the period of 14 days, based on the survival and death rate of the mice the potency unit of the vaccines were calculated by probit analysis software [5].

\section{Results and Discussion}

The vero cells are the best known host system for the propagation of many viral antigens including rabies virus. The upstream process like vero cell culturing, virus infection and harvesting are critical stage since different factors influence the propagation of virus. On the other part of vaccine manufacturing, the downstream processing play important role and there is a higher chance for product loss during purification, loss of antigenicity and stability of target protein component.

The rabies virus was propagated in Vero cells by roller bottle, bioreactor technology and used in this downstream processing study. It was observed that the virus titre in the different harvest ranging from $10^{-6.7}$ to $10^{-7.2}$ per $\mathrm{ml}$ of the harvest estimated by in-vitro cell culture method.

\section{Concentration of viral harvest}

The cellular debris in the viral harvest were removed by centrifugation and clarified by $0.45 \mu$ filtration before performing the concentration [12]. These cellular debris reduces the permeability of the viral harvest while performing the concentration through tangential flow ultra filtration with $100 \mathrm{kDa}$ MWCO cassettes. The cellular debris were removed by centrifuging the viral harvest at $2,500 \mathrm{~g}$ for 10 minutes under refrigerated $\left(4^{\circ} \mathrm{C}\right)$ condition, collected aseptically and clarified with $0.45 \mu$ filtration. The cross flow filtration / tangential flow filtration concentrate the virus by removing the water content along with the protein lesser than $100 \mathrm{kDa}$ molecular weight. The intact virus particles remain in the retentate and it was collected and inactivated with $\beta$ propiolactone in the concentration of 1:4000 after the removal of residual vero cell DNA in it.

\section{Test for virus inactivation}

Virus inactivation in the in-process biological material was ensured using three different methods namely Avirulece test, virus amplification in vero cells followed by animal inoculation and multiplex PCR targeting NP and MP genes of rabies virus. Absence of the rabies specific symptoms/ death in the sample inoculated animal model indicates the complete inactivation of the virus. In the virus amplification test, the sample is incubated with vero cells, if there is any live virus in sample will get amplified ( $14^{\text {th }} \& 21^{\text {st }}$ day harvest) and shows the symptoms/death while inoculated in to mice model.

The PCR can be used to ensure the virus inactivation as alternative test for Avirulece test and virus amplification test. The positive and negative controls results of multiplex PCR were analysed to validate the assay procedure by visualizing the specific amplified products with the positive control. The negative control was used to find out the false positive results due to cross contamination. The PCR is the highly sensitive 
method and reduces animal usage in in-process vaccine testing. The results shows that the inactivated sample doesn't have any amplified product while visualizing in agarose gel. The rabies virus specific Nucleoprotein gene (508bp) and matrix protein gene (293bp) were amplified in the positive control cDNA and internal control (live rabies virus processed in parallel with the inactivated sample) included in this testing procedure (Figure 1).

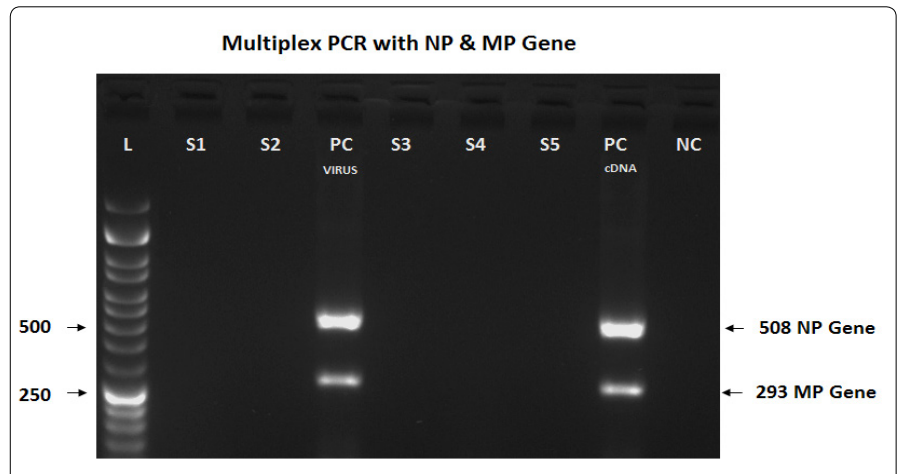

L: Iadder, S: Sample, PC: Positive Control \& NC Negative Control Figure 1. Invitro virus inactivation test by Multiplex PCR.

\section{Detection of rabies viral protein by HPLC \& Dot Blot}

HPLC based detection method for rabies viral protein was developed using the analytical column and used for detection in in-process biological preparation in comparison with the standard reference vaccine. The height of the specific HPLC peak is directly proportional to the concentration of the viral protein in the sample.

Three peaks were observed in the analytical column with the retention time of $1.20,1.38 \& 1.57$ in our final purified sample where as in the case of standard reference vaccine only two peaks with the retention time of $1.38 \& 1.57$ were observed (Figure: 2a \& 2b).

Further Dot blot based quantification of rabies viral protein is more suitable method for the quantification of rabies viral protein because the reaction involves with rabies antigen with specific antibody [14]. In every step of purification the HPLC and Dot Blot methods were used for rabies viral protein detection and quantification. The concentration of rabies viral protein in the dot blotted samples were extrapolated from the spectro-densitometer value in comparison with the reference standard included in the test. In some occasion, differences were observed in the protein content measured by HPLC was not reflected in the $\mathrm{NIH}$ potency as expected unit corresponding to the peak height of the reference standard. The results of NIH potency and Dot blot Hybridization were slightly varies, it may be due to different principles involved in in-vitro and in-vivo testing procedures.

\section{Purification of rabies viral protein by HPLC}

HPLC based purification method was developed for rabies viral protein from inactivated biological material using preparative column. The peak of rabies viral protein was identified (Figure: $2 c$ ) using the standard reference vaccine in the preparative column (retention time 0.35 ) and specifically collected based on the retention time. The collected peak was concentrated and dialysed using $10 \mathrm{kDa}$ dialysis tubes. The material was sterile filtered using $0.22 \mu$ filtration before formulating with two different stabilizers, preservative and lyophilized in the vials. The methods like ion exchange/affinity chromatography, sucrose density ultracentrifugation (zonal centrifugation) are alternative method for the purification of viral proteins $[6,15]$.

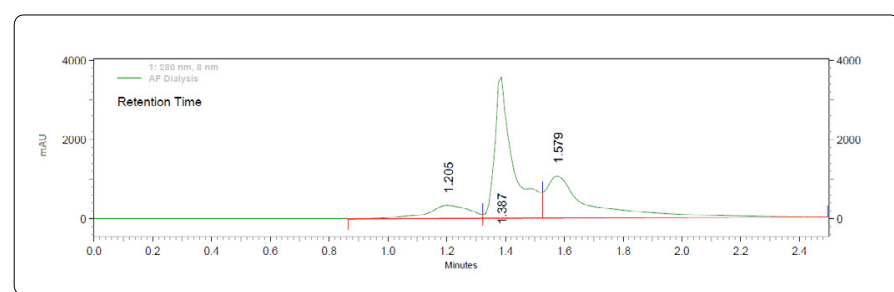

Figure 2a. HPLC analysis of rabies viral protein in sample by analytical column

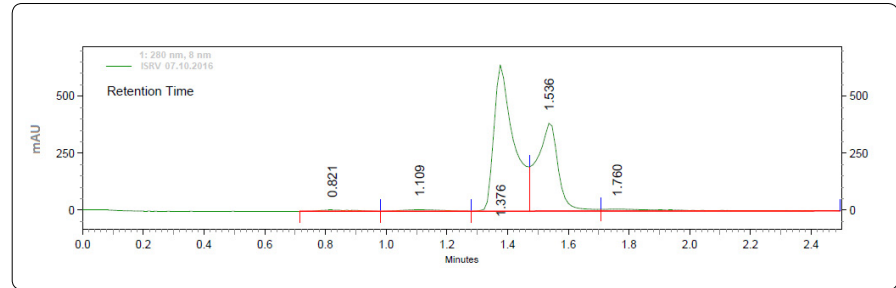

Figure $2 b$. HPLC analysis of rabies viral protein in reference standard by analytical column

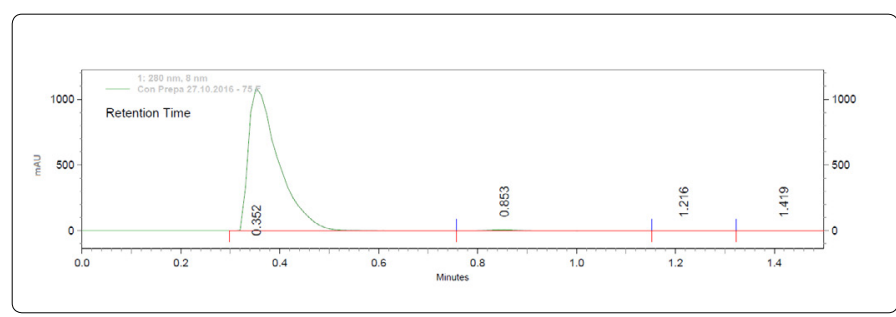

Figure 2c. HPLC analysis and rabies viral protein peak collected from preparative column

\section{Residual vero cell DNA}

The vero cells are continuous cell line and proven to be positive for carcinogenicity test after over 170 passages. The presence of residual vero cellular DNA in the vaccine could be oncogenic and poses a potential risk for human carcinogenesis [16]. Limit the residual Vero cellular DNA in downstream process and quantification in the vaccine is one of the quality requirement in the vaccine prepared from vero cell. Previously, maximum amounts of residual cellular DNA were set to 100 picograms per dose by the world health organization and it was revised to the limit of 10 nanograms per dose. $[5,17,18]$. The quantity of residual vero cell DNA in the different viral harvests, concentrated and purified material were monitored using real time based quantification technique (Figure 3a). It was estimated that per $\mathrm{ml}$ consist maximum of 94.85 picogram in viral harvest, 119.4 picograms in concentrated material and 23.6 picograms in final purified vaccine. The results of Vero cell DNA content quantified in different batches were tabulated in table 1 and graphically represented in (Figure 3b). 
Table 1. Residual vero cellular DNA (in picogram) in different stages of purification estimated by real time PCR.

\begin{tabular}{|c|c|c|c|c|c|c|}
\hline Batch & Harvest 1 & Harvest 2 & Harvest 3 & Harvest 4 & $\begin{array}{c}\text { CON } \\
\text { Material }\end{array}$ & $\begin{array}{c}\text { Final } \\
\text { Vaccine }\end{array}$ \\
\hline 1 & 38.835 & 28.385 & 25.825 & 94.85 & 68.8 & 4.985 \\
\hline 2 & 33.72 & 25.275 & 28.975 & 46.72 & 117.3 & 23.6 \\
\hline 3 & 48.305 & 24.335 & 26.055 & 34.755 & 116.1 & 18.105 \\
\hline 4 & 39.05 & 20.35 & 32.79 & 33.34 & 119.4 & 4.225 \\
\hline
\end{tabular}

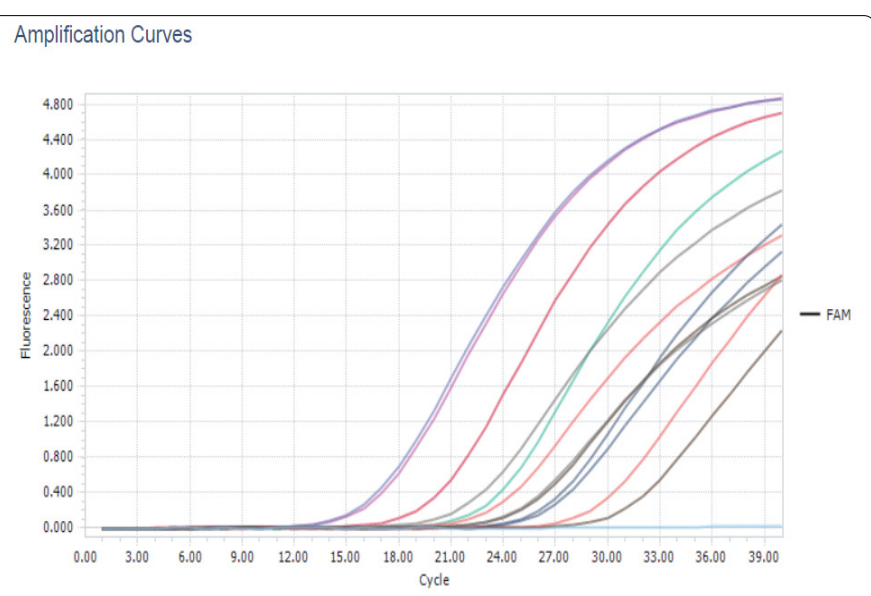

Figure 3a. Real time PCR amplification curve of vero cellular DNA

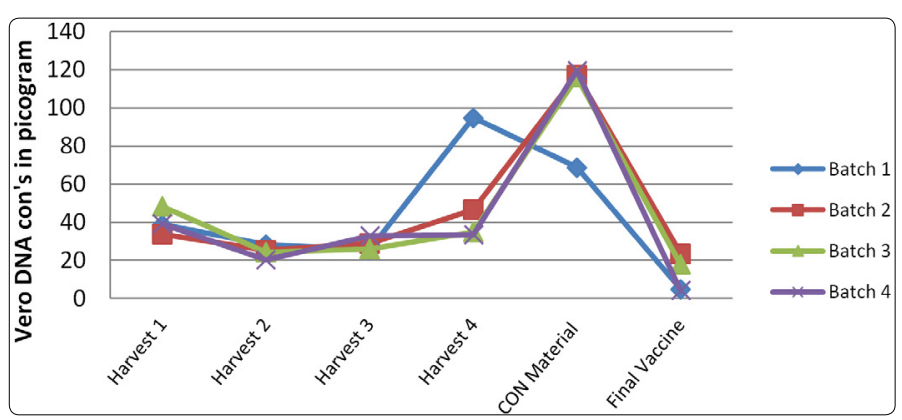

Figure 3b. Residual vero cellular DNA in different stages of purification estimated by real time PCR.

\section{NIH potency testing of rabies}

Potency analysis of final vaccines were done in mice model to estimate the potency unit of our vaccine preparation and the unit was calculated using the probit analysis in comparison with the reference standard included in the assay. The potency unit of 4 different samples from two different formulations were measured. The potency unit of Batch 1 formulations were 5.72 and $6.34 \mathrm{IU} /$ single dose and Batch 2 formulations were 2.80 and $2.89 \mathrm{IU} /$ single dose. Both the vaccines passes the minimum requirement of greater than 2.5 $\mathrm{IU} /$ single dose as specified in the WHO requirement $[5,18]$.

\section{Conclusion}

In the vaccine downstream process, the product loss is unavoidable and it can be minimized by implementing the suitable purification and detection methods. Also it is mandatory to remove / reduce the contaminants like cellular debris, residual vero cellular DNA to the acceptable level as specified by regulatory guidelines. The use of animal models in the vaccine research can be minimized by replacing suitable validated in-vitro methods to implement the 3 Rs concepts (Replacement, Reduction, Refinement of animal experiment).

\section{Acknowledgement}

The authors are grateful to $\mathrm{R}$ Krishnamurthy, $\mathrm{K}$ Ravichandran, M Subramani from R \& D Laboratory and N Chandran from Quality control laboratory (Pasteur Institute of India) for their technical support during this study.

\section{References}

1. Gongal G, Wright AE. Human Rabies in the WHO Southeast Asia Region: Forward Steps for Elimination. Advances in Preventive Medicine. 2011. doi: $10.4061 / 2011 / 383870$

2. Wunner WH, Briggs D. Rabies in the 21st Century. Plos Neglected tropical diseases. 2010; 4(3): e591.doi: 10.1371/journal.pntd.0000591

3. WHO. Expert consultation on rabies. Second report. World Health Organization Technical Report Series. 2013; 982: 1-139.

4. Orlowska A, Smreczak M, Trebas P, Żmudzinski JF. Comparison of RealTime PCR and Heminested RT-PCR methods in the detection of Rabies virus infection in Bats and terrestrial Animals. Bull Vet Inst Pulawy. 2008; 52(3): 313-318.

5. WHO. Recommendations for inactivated rabies vaccine for human use produced in cell substrates and embryonated eggs, Annex-2. World Health Organization Technical report series No. 2007; 941: 2007.

6. Neuza MFG, Regina MMF, Rosana LP, Maria L, Silva N. Vero cell rabies vaccine produced using serum free medium. Vaccine. 2004; 23(4): 511517. doi: 10.1016/j.vaccine.2004.06.014

7. Birhanu H, Abebe M, Bethlehem N, Sisay K, Gezahegn K. Production of Cell Culture Based Anti- rabies Vaccine in Ethiopia. Sci Verse Science Direct procedia in vaccinology. 2013; 7: 2-7. doi: 10.1016/j.provac.2013.06.002

8. Hurisa B, Tegbaru B, Nolkes D, Mengesha A, Kebede G, Kerga S, et.al. Safety and immunogenicity of ETHIORAB Rabies Vaccine. Journal of vaccines and vaccination. 2013; 4(6): 195. doi: 10.4172/2157-7560.1000195

9. Trabelsi K, Rourou S, Loukil H, Majoul S, Kallel H. Comparison of various culture modes for the production of rabies virus by vero cells grown on microcarriers in a $2 \mathrm{I}$ bioreactor. Enzyme and Microbial Technology. 2005; 36(4): 514-519. doi: 10.1016/j.enzmictec.2004.11.008

10. Srivastava AK, Putnak JR, Lee SH, Hong SP, Moon SB, Barvir DA, et al. A Purified inactivated Japanese encephalitis virus vaccine made in vero cells. Vaccine. 2001; 19(31): 4557-4565.

11. Rourou $S$, Ark AVD, Velden TVD, Kallel H. A microcarrier cell culture process for propagating rabies virus in vero cells grown in a stirred bioreactor under fully animal component free conditions. Vaccine. 2007; 25(19): 3879-3889.

12. Hong SP, Yoo WD, Putnak R, Srivastava AK, Eckels KH, Chung YJ, et al. Preparation of a purified, inactivated Japanese encephalitis (JE) virus vaccine in vero cells. Biotechnology letters. 2001; 23: 1565-1573. doi: 10.1023/A:1011917326672

13. Sekar T, Mohan GC, Karthick BS, Premkumar AA, Sundaran B, Sekar B Application of Reverse Transcriptase Nested, Hemi-Nested and Multiplex Polymerase Chain Reaction techniques for the detection of Pv 11, Pv 3462 and CVS strains of Rabies virus. International Journal of Pharma and Bio Sciences. 2018; 9(3): 280-286. doi: 10.22376/ijpbs.2018.9.3.b280-286

14. Sekar T, Mohan GC, Palaniappan C, Premkumar AA, Sundaran B, Sekar B. Development of In-vitro Assays to Estimate Rabies Viral Protein in Vaccine Preparation. Journal of Vaccines \& Vaccination. 2018; 9(3): 2018. doi: 10.4172/2157-7560.1000392

15. Toriniwa $\mathrm{H}$, Komiya T. Long-term stability of Vero Cell drived inactivated Japanese encephalitis vaccine prepared using serum-free medium. Vaccine. 2008; 26(29-30): 3680-3689. doi: 10.1016/j.vaccine.2008.04.076

16. Cao S, Dong G, Tang J, Li J, Liu J, Shi L, et al. Development of a Vero cell DNA reference standard for residual DNA measurement in China. Human vaccines \& immuno therapeutics. 2012; 9(2): 413-419. doi: 10.4161/hv.22699

17. Palacios JDCA, Barreto CAB, Lara JSM, Navas AML. Standardization of DNA Residual Quantification Method of Vero Cell Rabies Vaccine for Human Use. Open Med Chem J. 2017; 11: 66-80. doi: 10.2174/1874104501711010066

18. Indian pharmacopoeia. 2018. 